Review Article

www.ijrap.net

\title{
MAYONG: THE HERITAGE OF BLACK MAGIC AND TRADITIONAL TREATMENT
}

\author{
G. C. Nanda*
}

National Research Institute of Ayurvedic Drug Development, Bharatpur, Bhubaneswar, Odisha, India

Received on: 23/12/13 Revised on: 19/04/14 Accepted on: 22/04/14

\section{*Corresponding author}

Dr. Gopal C. Nanda, MD (Ayu), Ph. D, Assistant Director (Scientist-4) \& Head, National Research Institute of Ayurved Drug Development, Bharatpur, Near Kalinga Studio,Bhubaneswar, Pin- 751003, Odisha E-mail: nriadd.bhubaneswar@gmail.com DOI: $10.7897 / 2277-4343.05247$

\section{ABSTRACT}

Mayong, a village under morigaon district of Assam state, India is also known as village of magic or black magic. Usually the village has drawn the attention due to the traditional occult and folklore practice. Till today few people in the village maintain the tradition too. Not only, the traditional herbal practices but also the witchcraft was in practice by the people of this area. Several herbs have been used for both the purposes. Out of curiosity a tour was conducted to the village and several palm leaf manuscripts were found preserved with valuable information both on occult and folk practices. Attention was given to explore the remedial measures possible for further research on health issues through herbal formulations.

Keywords: Assam, Mayong-black magic, Ayurved-manuscript

\section{INTRODUCTION}

North-East is regarded as a $12^{\text {th }}$ bio hot-spot of global scenario. Not only for flora and fauna but for its cultural remaining, today $70 \%$ of the tribal population rely on the herbal medicine available in its environment which is a traditional way continuing from generation to generation ${ }^{1}$. These practices are documented in hand written manuscripts. Every village is having a tradition of Gaon bhura (head baij/Ojha) (Physician/Occult therapist) to treat all sorts of disease through herbal mixtures and chants (mantras) which is still in practice in the tribal areas of North-East ${ }^{2}$. Magic has always fascinated human minds. Whether it is children or grown ups, any form of magic still seems to enthrall them. The unsolved tricks, unanswered queries led to an unending curiosity about magic and its real existence. The interest in magic was revived after JK Rowling's Harry Potter and the Hogwarts School of Withes and Wizardy but Northeastern India seems to have its own real mesmerizing land of magicMayong. Mayong the village of magic where practitioners of the occult were rumored to have a predilection for turning people into creepy, crawling creatures, is ready to cast it's spell on people across the country in a more positive way. Apart from the seat of occult, the people of Mayong being rich in treating all sorts of ailments combining both occult and herbal mixtures. Today it also witnesses the traditional practitioners in its vicinity. Magical Mayong a small village in the Morigaon district of Assam, India. Mayong has always been famous as the land of black magic and mystery. It is a remote and interior region on the outskirts of Nagaon district and has been famous for School of Magic Art since the days of the Yogini Tantra. There are citations of Mayong and Pragiyotishpura in several mythological epics including the Mahabharata, King Ghatotkacha of Pragiyotishpura took part in the Mahabharata war with his magical powers. Legend has it that centuries ago, a king of Nepal brought magic to the Brahmaputra valley. He established a small kingdom. Rajamayong became its capital and the Burhamayong evolved as the firmament of radical tantrism. Through the glorious era of the Ahom, the natives diligently nurtured the magic of Mayong. Even today, the few people of Mayong are true followers of those beliefs, which they consider as God gifted capabilities for solving their day-to-day problems and they still depend on magic and their indigenous herbs. Mayong throughout history is only known for its black magic and occult practices. Again, there is a lot of conflict regarding the origin of the name "Mayong". Some propose that the name originated from Maya, which indicates illusion and fascination, while others hold that Manipuris from the maibong clan used to inhibit this area and therefore, the name Maibong became Mayong with the passage of time. This enchanting destination has a lot of appeal since past. It is an unexplored treasure chest of magic, spells and occult practices. It was a regular habit for people of this region to depend on magic even for their daily chores. This magical land has a treasure of magic peculiar to itself and boasts of being the only capital of black magic in the whole of Assam, India. This land was the home to some rare tricks which may look like aberrant practices in the backdrop of modern era but are substantial enough to make someone to re-think about the existence of magic. Among many such tricks are fortunes telling via korris (sea shells), palmistry, and future projection through a piece of broken glass, which are almost unbelievable. Not only this, here magic is also used to cure the illnesses of the local populace. The people cut a handful of plants and recite some spells or mantras, whatever one may prefer to call them, and the ailing person experiences immediate relief ${ }^{3}$, However, one of the most outstanding magic acts, which still exist, is the curing of back pain via village witch doctor who utters a magic chant and uses a copper dish to track where the pain originates. The plate gets stuck to the body and the local believe that this dish eats away the pain. The local witch doctor demonstrates the magical act and if the person is really suffering from back pain, then the copper dish becomes hot like fire within seconds and it gets smashed automatically. Besides, this thrilling place also 
boasts of mantras to create attraction between two individuals. They have the Mohini mantra, Boshikaran etc. People in the olden days in Mayong claimed to have the power of moving to any place they wanted within minutes by the use of the uran mantra or the chant to fly. A few households at Rajamayong and Buramayong still possess some of the manuscripts in a lesser from. Knowing the amazing history of mayong, the village with black magic and occults a curiosity arises by the author during his tenure at Guwahati, Assam, India and planned to visit the place along with few staff of the Regional Research Institute of Ayurveda, Guwahati, Assam, India. Several places were visited with old people/traditional practitioners of this area. It was also an opportunity to visit a museum situated amidst the forest of pobitora wild life sanctuary which was running by the help of local people of this area to keep the heritage alive. The museum holds a lot of materials starting from palm leaf manuscripts to terracotta items, bronze items with archeological importance of more than century old. The author took interest to examine the palm leaf manuscripts found unfolded for years together known to be items of the museum. However, it was desired by the Author to have a glance over the palm leaf manuscripts. The old and original manuscripts of magic containing the spells and magic words were still preserved by the oldest living individuals of the village

\section{Enumeration of Palm Leaf Manuscripts}

The lists of manuscripts tabulated bear a little information. It can only be confirmed about the specification/content after thorough reading of literature in detail.

\begin{tabular}{|c|c|c|c|c|}
\hline S. No. & Name of the Manuscripts & Numbers & Conditions & Remarks/Subject/Contents \\
\hline 1. & Sannipat jara Mantra & 1 & Complete/good & $\begin{array}{l}\text { Treatment of sanipat jwara with various chants along with some herbal } \\
\text { mixtures. }\end{array}$ \\
\hline 2. & Sarpa maniraja Mantra & 1 & -do- & $\begin{array}{l}\text { Treatment of snake bite with mantra and herbal mixtures. The herbs } \\
\text { described to be used in snake bite are written in local assamese language. }\end{array}$ \\
\hline 3. & Kalam Mantra & 2 & Incomplete/good & $\begin{array}{l}\text { The manuscript is written in regional language with some mantra for } \\
\text { various purposes. }\end{array}$ \\
\hline 4. & Shingimari Jhara Mantra & 1 & Complete/good & $\begin{array}{l}\text { The manuscript describes about certain antidote for sting bite by specific } \\
\text { fish varieties along the some herbal application. }\end{array}$ \\
\hline 5. & Gokarati Mantra & 2 & Incomplete/good & $\begin{array}{l}\text { Treatment for cows (Veterinary medicine. The manuscripts describes } \\
\text { about various diseases and their remedial measures through mantra and } \\
\text { medicinal plants. }\end{array}$ \\
\hline 6. & Vayu Mantra & 5 & Complete/Good & $\begin{array}{l}\text { Neurological disorders. There are certain mantras found for various magic } \\
\text { performances in this manuscript. }\end{array}$ \\
\hline 7 & Rudra Kariti Mantra & 2 & $\begin{array}{ll}\text { No } & \text { Colophon } \\
\text { Good }\end{array}$ & $\begin{array}{l}\text { The manuscript is not having colophon but } \\
\text { bears few descriptions on remedial measures to diseases with herbs and } \\
\text { mantra }\end{array}$ \\
\hline 8. & Murar Mantra & 1 & Complete/Good & $\begin{array}{l}\text { Treatment for Head. The manuscript describes certain mantra and herbal } \\
\text { application for various conditions of mental faculties. }\end{array}$ \\
\hline 9. & Harajhara Mantra & 1 & Incomplete/Good & $\begin{array}{l}\text { Few portions of the manuscript contain some mantra along with herbal } \\
\text { application for bone diseases especially fracture and joints dislocation. }\end{array}$ \\
\hline 10. & Ban Kata Mantra & 1 & Complete/Good & $\begin{array}{l}\text { The manuscript deals with the remedial measure for harmful application to } \\
\text { human being with its remedial measures. }\end{array}$ \\
\hline 11. & Manuhar apakarkara Mantra & 1 & Incomplete/Good & $\begin{array}{l}\text { Treatment/black magic. It contains certain Chants/Mantra which can harm } \\
\text { human being, if applied. }\end{array}$ \\
\hline 12. & Sridevahara Mantra & 1 & Incomplete/Good & It contains certain Chants/ Mantra. \\
\hline 13. & Rakshya Mantra & 1 & Incomplete/Good & Few Mantras are described for protection from various evil effects. \\
\hline 14. & Rajagharia Mantra & 1 & Incomplete/Good & $\begin{array}{l}\text { Certain Mantras/Chants are written which were in use by kings for } \\
\text { specific purposes. }\end{array}$ \\
\hline 15. & Mantra Pothi & 1 & Incomplete/Good & A Manuscript with various mantras for different purposes. \\
\hline 16. & Mohini Mantra & 1 & Incomplete/Good & $\begin{array}{l}\text { A typical manuscript for basikarn or mesmerism to bring any person under } \\
\text { control with herbal mixture and mantra. }\end{array}$ \\
\hline 17. & Gurudiksha Mantra & 1 & Incomplete/Good & $\begin{array}{l}\text { Few mantras were written for a person to get a guru to learn or before } \\
\text { going to apply the mantra how it is being learnt from the teacher. }\end{array}$ \\
\hline 18. & $\begin{array}{l}\text { Mahabharata SabhaParba }(1 \\
\text { Part) }\end{array}$ & 1 & Incomplete/Good & Legendary the description on part of Mahabharata \\
\hline 19. & Narasingha Mantra & 1 & Incomplete/Good & $\begin{array}{l}\text { The manuscript deals with certain mantra/chants in the name of } \\
\text { Narasingha for protection. }\end{array}$ \\
\hline 20. & Dharani Mantra & 1 & Incomplete/Good & Few mantras with regional descriptions related to black magic. \\
\hline 21. & Without caption & 20 & Incomplete/Good & $\begin{array}{l}\text { These manuscripts are found without any caption and the conditions of } \\
\text { these manuscripts are not so good. However they contain mantras only. }\end{array}$ \\
\hline
\end{tabular}

\section{CONCLUSION}

This place is the home of magic in north eastern India or may be even the whole of India. The natives of this place know their magic well. They have inherited this art over the centuries from their ancestors and still take pride in practicing it and talking about it. It reveals that the practitioners are still in force though not through occult, but from the vast flora and fauna for the ailments. A lot of information is buried under these manuscripts and the time has come to locate, preserve and document this information. Further steps are needed to explore more numbers of manuscripts of this region with proper documentation and clinical validation. The time has come to explore the remedial measures through herbal assistance for their genuineness to the context usefulness towards human being welfare available in various old literatures in the hidden form. 


\section{ACKNOWLEDGEMENT}

The Author is thankful to Director General, CCRAS for inspiring and giving the moral support. The Author is also equally thankful to Mr. S. R. Talukdar, SRF (Botany), NEIARI, Guwahati, Assam, India Mr. Utpal Nath, lecturer (Economics) of Mayong College cum Secretary of Mayong Central Museum for providing related information.

Disclaimer

We do not support or promote black magic of any kind but the paper is based on the collection of information related to century old manuscripts having some buried medical prescription. The place is known century old for its name as "black magic village". We have tried to provide the information for future research to explore the formulation available in the manuscript for wider benefit of human health, if any.

\section{REFERENCES}

1. Basu Sahi, Tribal Health Care India, Mank Publications Pvt., Ltd., New Delhi-53; 1994.

2. Kakar DN. Primary Health Care and Traditional medical practitioners, SK Gahi, Managing Director, Sterling Publishers pvt. Ltd., Green Park, New Delhi-16.

3. Kanjilal UN. Flora of Assam Vol. I to Vol. V, Allied Book Centre 15-A, Rajpur Road, Deradun; 1991.

4. Nath J. Cultural Heritage of Tribal Societies, R Kumar, Omsons publication, New Delhi; 2000.

5. Ray Verman JJ. Tribal medicines, Mittal Publications, Mohan Garden, New Delhi-59

6. Sen Soumen, Folklore in North-East India, Omsons publication, 77, Rajouri Garden, New Delhi; 1985.

Cite this article as:

G. C. Nanda. Mayong: The heritage of black magic and traditional treatment. Int. J. Res. Ayurveda Pharm. 2014;5(2):235-237 http://dx. doi.org/10.7897/2277-4343.05247 